\title{
Hemodynamics and tissue oxygenation effects after increased in positive end- expiratory pressure in coronary artery bypass surgery
}

Vanessa Marques Ferreira Méndez ${ }^{1,2}$, Mayron F. Oliveira ${ }^{1,3^{*}}$, Adriana do Nascimento Baião ${ }^{1,2}$, Patrícia Andrade Xavier ${ }^{1,2,4}$, Carlos Gun ${ }^{5}$, Priscila A. Sperandio ${ }^{1}$ and Iracema I. K. Umeda ${ }^{1}$

\begin{abstract}
Background: Cardiac surgery is widely used in the treatment of cardiovascular diseases. However, several complications can be observed during the postoperative period. Positive end expiratory pressure (PEEP) improves gas exchange, but it might be related to decreased cardiac output and possible impairment of tissue oxygenation. The aim of this study was to investigate the hemodynamic effects and oxygen saturation of central venous blood $\left(\mathrm{ScVO}_{2}\right)$ after increasing PEEP in hypoxemic patients after coronary artery bypass (CAB) surgery.

Methods: Seventy post-cardiac surgery patients (CAB), $61 \pm 7$ years, without ventricular dysfunction (left ventricular ejection fraction $57 \pm 2 \%$, with hypoxemia $\left(\mathrm{PaO}_{2} / \mathrm{FiO}_{2}\right.$ ratio $\left.<200\right)$ were enrolled. Heart rate, mean arterial pressure, arterial and venous blood samples were measured at intensive care unit and PEEP was increased to 12 $\mathrm{CmH}_{2} \mathrm{O}$ for 30 min.

Results: As expected, PEEP12 improved arterial oxygenation and $\mathrm{PaO}_{2} / \mathrm{FiO}$ ratio $(p<0.0001)$. Reduction in $\mathrm{ScvO}_{2}$ was observed between PEEP5 $(63 \pm 2 \%)$ and PEEP12 $(57 \pm 1 \% ; p=0.01)$ with higher values of blood lactate in PEEP12 $(p<0.01)$. No hemodynamic effects (heart rate, mean arterial pressure, $\mathrm{SpO}_{2} ; p>0.05$ ) were related.

Conclusion: Increased PEEP after cardiac surgery decreased $\mathrm{ScvO}_{2}$ and increased blood lactate, even with higher $\mathrm{O}_{2}$ delivery. PEEP did not interfere in hemodynamics status in CAB patients, suggesting that peripheral parameters must be controlled and measured during procedures involving increased PEEP in post-cardiac surgery patients in the intensive care unit.
\end{abstract}

Keywords: PEEP, $\mathrm{ScvO}_{2}$, Cardiac surgery, Hemodynamics, Physiotherapy

\section{Background}

Coronary artery bypass $(\mathrm{CAB})$ surgery is widely used in cardiovascular treatment and, during procedure, patients are exposed to anesthesia and cardiopulmonary bypass. This exposure is one of the most important cause of pulmonary dysfunction in the postoperative period with higher levels of morbidities [1]. Moreover, anesthesia

\footnotetext{
* Correspondence: mayronfaria@hotmail.com

'Physiotherapy Unit, Dante Pazzanese Institute of Cardiology, Avenida Dr Dante Pazzanese, 500, CEP: 04012-180, Vila Mariana, São Paulo, SP, Brazil ${ }^{3}$ Physiotherapy Unit, Division of Health Sciences Centre, University of Fortaleza (UNIFOR), Fortaleza, CE, Brazil

Full list of author information is available at the end of the article
}

might be responsible for reduced pulmonary volume, atelectasis and reduced oxygenation [1].

In this scenario, positive end expiratory pressure (PEEP) has commonly been used to reverse atelectasis and hypoxemia [2]. However, PEEP could interfere in intra-thoracic pressure, which can reduce venous return and cardiac output [3], which in turn can affect tissue perfusion and delivery/utilization.

The influence of PEEP on cardiac output and tissue oxygenation can be measured by oxygen saturation of central venous blood $\left(\mathrm{ScvO}_{2}\right)$ [3] and values under $70 \%$ suggest low oxygen delivery/utilization and are predictive of a poor prognosis during postoperative period [3]. 
However, there are few studies that evaluated the hemodynamic effects of PEEP and $\mathrm{ScvO}_{2}$ in patients after cardiac surgery $(\mathrm{CAB})$. Therefore, the aim of this study was to evaluate hemodynamic effects and tissue oxygenation measured by $\mathrm{ScVO}_{2}$ in two levels of PEEP in patients after $\mathrm{CAB}$.

\section{Methods}

Post elective cardiac surgery patients $(\mathrm{CAB})$, over 40 years, with hypoxemia $\left(\mathrm{PaO}_{2} / \mathrm{FiO}_{2}\right.$ ratio $\left.<200\right)$ and hemoglobin $>10 \mathrm{~g} / \mathrm{dL}$ were enrolled. Patients with hemodynamic instability (heart rate $<50 \mathrm{bpm}$ or $>140 \mathrm{bpm}$ ), mean arterial pressure $<60 \mathrm{mmHg}$ or $>140 \mathrm{mmHg}$, norepinephrine dosage $>0.03 \mathrm{mcg} / \mathrm{kg} / \mathrm{min}$ and left ventricular ejection fraction $<40 \%$ were excluded.

After undergoing cardiovascular surgery, all of the patients were admitted to the intensive care unit (ICU) and immediately arterial and central venous blood sample were collected and submitted for blood gas analysis (865(R) blood gas analyzer; Chiron Diagnostics, England). The catheter's for venous blood sample was located at the right atrium and the correct position was checked accordingly to the institutional protocol. Heart rate, mean arterial pressure, and oxyhemoglobin saturation by pulse oximetry $\left(\mathrm{SpO}_{2}\right)$ were measured with a Dixtal monitor (DX 2010 $)$; volemic status (water balance) was also monitored during surgery and into the protocol. All patients were admitted at ICU and followed the institutional mechanical ventilation protocol with volume-controlled (PEEP $5 \mathrm{cmH}_{2} \mathrm{O}$, respiratory rate 14 breaths per minute, $\mathrm{FiO}_{2} 0.4$, tidal volume of 6-8 $\mathrm{mL} / \mathrm{kg}$ ) and PEEP was increased to $12 \mathrm{cmH}_{2} \mathrm{O}$ for $30 \mathrm{~min}$ in all patients with arterial hypoxemia $\left(\mathrm{PaO}_{2} / \mathrm{FiO}_{2}\right.$ ratio <200) (Fig. 1). After $30 \mathrm{~min}$, all variables were measured and the protocol was ended.

Study protocol was interrupted and PEEP was returned to $5 \mathrm{cmH}_{2} \mathrm{O}$ if there was drop in $\mathrm{SpO}_{2}$ below than $90 \%$, increased in $\mathrm{FiO}_{2}$, mean arterial pressure $<70 \mathrm{mmHg}$ or bleeding $>200 \mathrm{~mL}$. All subjects provided written informed consent, and the study was approved by the Medical Ethics Committee of the Dante Pazzanese Institute of Cardiology, São Paulo, Brazil (protocol number 3535).

\section{Statistical analysis}

Statistical analysis was carried out using the SPSS program (version 18.0. Chicago: SPSS Inc.). The KolmogorovSmirnov test was used to determine normality of the data distribution. Categorical variables were presented in absolute frequencies and percentage values. Continuous variables of parametric distribution were presented as mean \pm standard deviation (SD) and, when appropriated, median

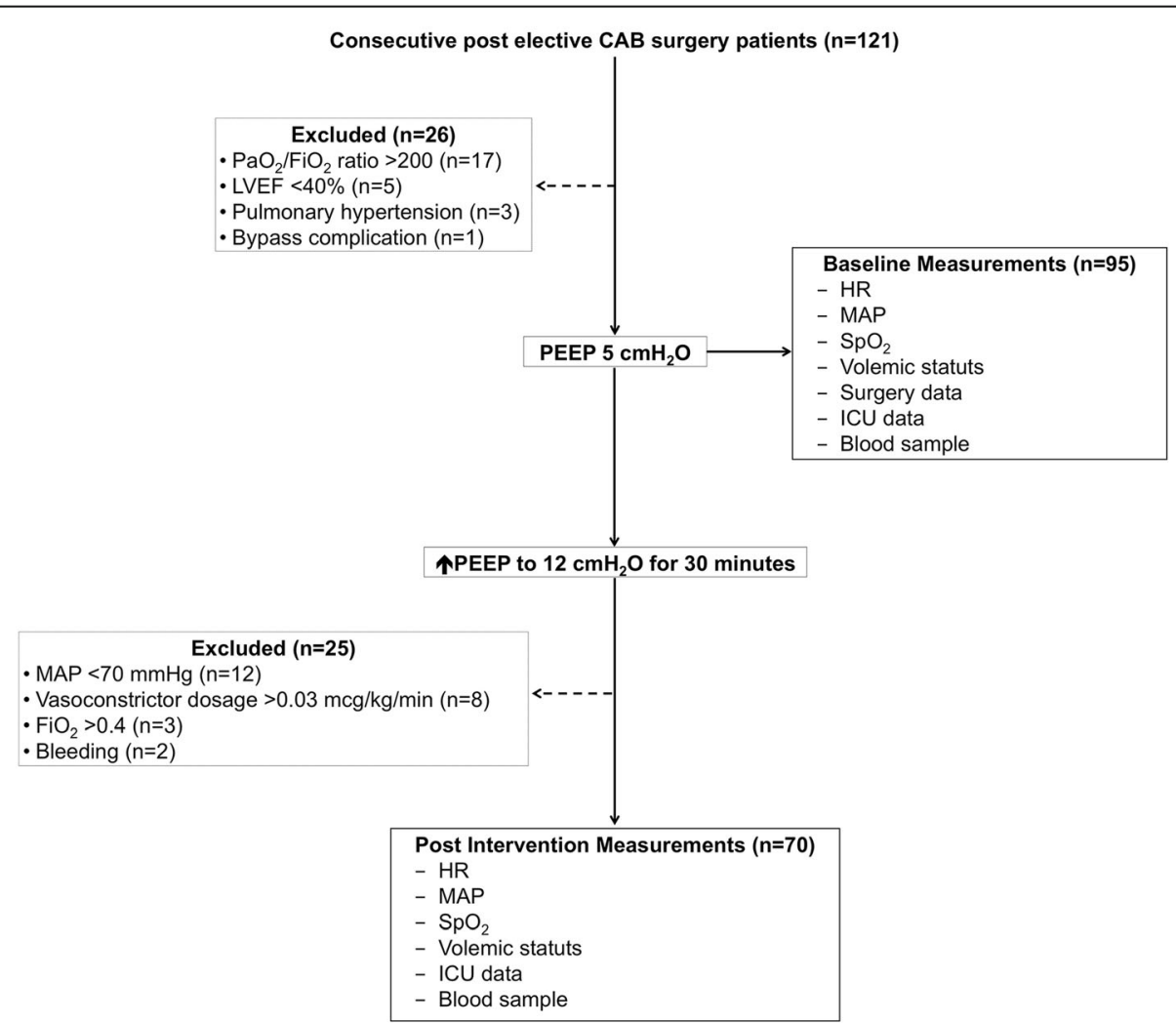

Fig. 1 Flowchart of input in the study. Figure notes: $L V E F=$ left ventricular ejection fraction; $H R=$ heart rate; MAP = mean arterial pressure; $\mathrm{SpO}_{2}=$ hemoglobin saturation by pulse oximetry; $\mathrm{ICU}=$ intensive care unit; $\mathrm{FiO}_{2}=$ oxygen support 
[minimum value; maximum value] for variables of non-parametric distribution. Paired T-test and MannWhitney were used for comparisons between conditions. For all the analyses the statistical significance was accepted when $p<0.05$.

\section{Results}

One hundred and twenty one consecutive post elective cardiovascular surgery patients were enrolled in this study and none of the patients had pulmonary disease, heart failure or renal insufficiency prior to surgery; fiftyone patients were excluded (bypass complication; LVEF $<0.4$; pulmonary hypertension; bleeding; $\mathrm{MAP}<70 \mathrm{mmHg}$; vasopressor medication $>0.03 \mathrm{mcg} / \mathrm{kg} / \mathrm{min}$; higher oxygen support $\left.-\mathrm{FiO}_{2}>0.4\right)$; afterwards seventy patients were included in the study (Fig. 1).

Baseline characteristics are shown in Table 1. There were a higher percentage of male patients (77\%) (Table 1 ) and, during surgery procedure, 50 patients $(71 \%)$ had positive volemic status, and it remained positive during the stay in the intensive care unit, at both PEEP 5 $\mathrm{cmH}_{2} \mathrm{O}(180 \pm 82 \mathrm{~mL})$ and PEEP $12 \mathrm{cmH}_{2} \mathrm{O}(197 \pm$ $78 \mathrm{~mL})(p>0.05)$. It should be noted that during the protocol all patients had 0.4 of oxygen support.

As expected, $12 \mathrm{cmH}_{2} \mathrm{O}$ of PEEP increased $\mathrm{PaO}_{2}$ and improved $\mathrm{PaO}_{2} / \mathrm{FiO}_{2}$ ratio (Table 2). Moreover, no

Table 1 Patient's characteristics and surgical data in seventy patients after $C A B$ surgery

\begin{tabular}{ll}
\hline Anthropometrics/Demographics & \\
Age, years & $61 \pm 7$ \\
Weight, kg & $73 \pm 10$ \\
Height, m & $1.63 \pm 0.11$ \\
BMl, kg/m² & $27 \pm 4$ \\
LVEF, \% & $57 \pm 2$ \\
EuroSCORE, median (min-max) & $5(3-9)$ \\
ICU, days & $2 \pm 1$ \\
Mechanical ventilation time, hrs & $6 \pm 2$ \\
Hospital length of stay, days & $7 \pm 2$ \\
Main comorbidities & \\
Hypertension, $\mathrm{n}$ (\%) & $64(91 \%)$ \\
Dyslipidemia, $\mathrm{n}(\%)$ & $52(74 \%)$ \\
Diabetes, $\mathrm{n}$ (\%) & $40(57 \%)$ \\
Ex-smoker, $\mathrm{n}$ (\%) & $35(50 \%)$ \\
Surgical data & \\
Partial thromboplastin time activated, s & $19 \pm 8$ \\
Cardiopulmonary bypass time, min & $107 \pm 22$ \\
Cross-clamp time, min & $61 \pm 17$ \\
\hline
\end{tabular}

Abbreviations: BMI body mass index, LVEF left ventricular ejection fraction, EuroSCORE European System for Cardiac Operative Risk Evaluation. Data are expressed as mean values \pm standard deviation, unless specified
Table 2 Hemodynamic and tissue oxygenation in seventy patients after $C A B$ surgery

\begin{tabular}{|c|c|c|c|}
\hline & PEEP 5 & PEEP 12 & $p$-value \\
\hline $\mathrm{HR}$, bpm & $97 \pm 16$ & $92 \pm 14$ & 0.02 \\
\hline SAP, mmHg & $109 \pm 13$ & $122 \pm 17$ & 0.12 \\
\hline $\mathrm{DAP}, \mathrm{mmHg}$ & $77 \pm 16$ & $81 \pm 12$ & 0.58 \\
\hline MAP, mmHg & $89 \pm 15$ & $93 \pm 13$ & 0.65 \\
\hline Double product & $10593 \pm 411$ & $11214 \pm 459$ & 0.17 \\
\hline Central venous pressure, $\mathrm{mmHg}$ & $7 \pm 2$ & $8 \pm 3$ & 0.96 \\
\hline $\mathrm{SpO}_{2}, \%$ & $94 \pm 3$ & $96 \pm 3$ & 0.89 \\
\hline $\mathrm{V}_{T}, \mathrm{~mL}$ & $597 \pm 121$ & $613 \pm 130$ & 0.33 \\
\hline $\mathrm{RR}$, ripm & $14 \pm 1$ & $14 \pm 2$ & 0.99 \\
\hline Catecholamine & $12(17 \%)$ & $15(21 \%)$ & 0.21 \\
\hline \multicolumn{4}{|l|}{ Blood sample } \\
\hline $\mathrm{Hb}, \mathrm{g} / \mathrm{dL}$ & $12 \pm 1$ & $12 \pm 2$ & 0.92 \\
\hline $\mathrm{pH}$ & $7.37 \pm 0.07$ & $7.35 \pm 0.06$ & 0.05 \\
\hline $\mathrm{PaO}_{2}, \mathrm{mmHg}$ & $70.2 \pm 6.2$ & $112.8 \pm 2.1$ & $<0.0001$ \\
\hline $\mathrm{PaCO}_{2}, \mathrm{mmHg}$ & $38.6 \pm 8.8$ & $38.7 \pm 7.8$ & 0.96 \\
\hline $\mathrm{HCO}_{3}^{-}$ & $22.1 \pm 2.3$ & $21.8 \pm 1.6$ & 0.03 \\
\hline $\mathrm{BE}$ & $-2.4 \pm 0.8$ & $-3.5 \pm 0.6$ & 0.04 \\
\hline $\mathrm{SaO}_{2}, \%$ & $93 \pm 3$ & $97 \pm 2$ & 0.02 \\
\hline $\mathrm{PaO}_{2} / \mathrm{FiO}_{2}$ ratio & $179 \pm 24$ & $271 \pm 38$ & $<0.0001$ \\
\hline $\mathrm{ScvO}_{2}, \%$ & $63 \pm 5$ & $57 \pm 3$ & 0.01 \\
\hline Lactate, mmol/L & $3.2 \pm 1.1$ & $6.7 \pm 1.5$ & 0.001 \\
\hline
\end{tabular}

Abbreviations: $H R$ heart rate, $b p m$ beats per minute, SAP systolic arterial pressure, DAP diastolic arterial pressure, $M A P$ mean arterial pressure, $\mathrm{SpO}_{2}$ hemoglobin saturation by pulse oximetry, $V_{T}$ tidal volume, $R R$ respiratory rate, ripm respiratory incursion per minute, $\mathrm{Hb}$ hemoglobin, $\mathrm{pH}$ hydrogen potential, $\mathrm{PaO}_{2}$ arterial oxygen pressure, $\mathrm{PaCO}_{2}$ arterial carbon dioxide pressure, $\mathrm{HCO}_{3}^{-}$ bicarbonate, $\mathrm{BE}$ base excess, $\mathrm{SaO}_{2}$ arterial oxygen saturation, $\mathrm{ScVO}_{2}$ oxygen saturation of central venous blood. Values are expressed in mean \pm standard deviation or frequency

differences in carbon dioxide pressure $\left(\mathrm{PaCO}_{2}\right)$ were observed between the two interventions. On the other hand, increased PEEP significantly reduced tissue oxygenation observed by $\mathrm{ScvO}_{2}$ with higher values of blood lactate but without difference in MAP or in central venous pressure (Table 2).

Most patients were discharged from the intensive care unit on the second day and with low mechanical ventilation time (Table 1). None of the patients included in the study experienced cardiac outcome or death after the protocol.

\section{Discussion}

In the present study we investigated the influence of PEEP on hemodynamics and tissue oxygenation in patients after $C A B$. It should be noted that increases in PEEP caused a significant reduction in tissue oxygenation $\left(\mathrm{ScvO}_{2}\right)$, even with higher levels of oxygen delivery $\left(\mathrm{PaO}_{2}\right.$ and $\mathrm{PaO}_{2} / \mathrm{FiO}_{2}$ ratio). 
Collapsed lung and hypoxia are common complications after cardiac surgery, mainly due to anesthesia (decreased muscle tone and predisposition to atelectasis) [4] and these changes may be accentuated by surfactant reduction and inflammatory response. In addition, the inflammatory process contributes to pulmonary interstitial edema, which cause a significant decrease in pulmonary gas exchange [5]. Our results indicate increases in $\mathrm{PaO}_{2}$, oxygen hemoglobin saturation, and $\mathrm{PaO}_{2} / \mathrm{FiO}_{2}$ ratio, suggesting a reversal of alveolar collapse. These results are consistent with those found in the scientific literature, mainly in patients with acute respiratory distress syndrome [5]. Studies have shown that higher values of PEEP can prevent hypoxemia, with a significant increase in $\mathrm{PaO}_{2}$ in post-cardiac surgery patients [5-7].

Despite the benefits of high PEEP after cardiac surgery in improving oxygenation, some precautions should be taken with PEEP increases in patients at the intensive care unit, mainly because PEEP might interfere with intra-thoracic pressure with hemodynamic effects. Some studies have demonstrated that reductions in cardiac output and tissue oxygenation could occur after increased PEEP $[4,8]$. Moreover, different PEEP levels reduced cardiac output without changes in $\mathrm{PaO}_{2} / \mathrm{FiO}_{2}$ ratio, $\mathrm{ScvO}_{2}$, or hemodynamic values (heart rate or mean arterial pressure). The authors suggested that the reduced cardiac output was due to high levels of PEEP, as cardiac output was restored after PEEP decreased to $5 \mathrm{cmH}_{2} \mathrm{O}$ [8].

Studies of normovolemic patients have reported maintenance of cardiac output after increased PEEP [9]. However, it should be noted that our study exhibited positive water balance and higher values of blood lactate after study protocol, suggesting that increased PEEP values were responsible for reducing cardiac output and, consequently, for reductions in tissue oxygenation (lower $\mathrm{ScvO}_{2}$ values). Recently, Gutierrez (2016) [10] described a higher respiratory muscle workload with a decreased $\mathrm{ScvO}_{2}$ and this finding was not associated with sepsis. Furthermore, Rivers et. al. (2001) [11] demonstrated that increases in $\mathrm{ScvO}_{2}$ should have been related to respiratory muscles unloading by mechanical ventilation. Our study was not designed to access the respiratory muscle function (overloading or unloading) by PEEP increases, but this fact might have influenced the reduction in $\mathrm{ScvO}_{2}$ values. This issue should be performed in further studies with PEEP hemodynamics after CAB surgery. Moreover, some studies have demonstrated that higher levels of PEEP required more sedatives and increase the mechanical ventilation time and compromise the mechanical ventilation withdrawal $[6,12,13]$. Our data support the notion that high PEEP levels directly affect tissue oxygenation in patients after cardiac surgery, even with preserved cardiac function and without surgery complications. However, it should be noted that our protocol did not measure cardiac output directly and we suggest a reduction in cardiac output using $\mathrm{ScvO}_{2}$.

Moreover, some studies have reported that short periods of increased PEEP may be beneficial to post-cardiac surgery patients without compromising hemodynamic or tissue oxygenation [14]. In this scenario, even in short periods of high PEEP levels, certain precautions should be taken, such as $\mathrm{ScvO}_{2}$ measurements. Our results suggest a reduction in tissue oxygenation and higher levels of blood lactate during only $30 \mathrm{~min}$ of rising PEEP; and it has been demonstrated that reductions in $\mathrm{ScvO}_{2}$ are related to poor outcomes after cardiac surgery. The maintaining $\mathrm{ScvO}_{2}$ above $70 \%$ resulted in a reduction in mortality [15] and our findings support our suggestions that $\mathrm{ScvO}_{2}$ should be monitored in patients without cardiac failure or without surgery complications.

\section{Study limitations}

Some limitations of this study should be addressed. The inclusion criteria of $\mathrm{PaO}_{2} / \mathrm{FiO}_{2}$ ratio $<200$ may have limited the number of patients in our study. Thus the extrapolation of our findings to other studies of $\mathrm{CAB}$ surgery should be viewed with caution. On the other hand, there is evidence that the $\mathrm{PaO}_{2} / \mathrm{FiO}_{2}$ ratio $<200$ is the most common hypoxemia finding after $\mathrm{CAB}$ surgery [16] and $\mathrm{PaO}_{2}$ alterations in patients after $\mathrm{CAB}$ surgery do not depend on PEEP only but the level of $\mathrm{O}_{2}$ delivery/utilization ratio [11]. Moreover, we did not measure cardiac output before or after PEEP increase, which could have better demonstrated tissue oxygen delivery and utilization. Rather, $\mathrm{ScvO}_{2}$ values were used to reflect tissue oxygen delivery and utilization indirectly during the PEEP maneuver. The venous blood sample has been taken by a catheter positioned in right atrium, we recognize that this could rise some questions, but all patients had normal right ventriculum and with adequate volemic status and central venous pressure. Further studies with Swan-Ganz catheter should be performed to access the directly effect of hemodynamics repercussions with PEEP in hypoxemic $\mathrm{CAB}$ patients. We believe that $\mathrm{ScvO}_{2}$ is a good alternative to measure whole-body oxygen extraction, it is minimally invasive and have low cost. In addition, our results demonstrated positive water balance during the intensive care unit, but other measurements could also have been addressed, such as Swan-ganz catheter. Moreover, we did not measure the inflammation status after cardiac surgery or after PEEP maneuver.

Our study aimed to evaluate the hemodynamics effects after PEEP increases, and we recognize that a control group, without PEEP increases, was not performed; but the PEEP titration was not main objective of the study; we aimed to investigate hemodynamics and tissue oxygenation after a simple PEEP increase in hypoxemic patients after $\mathrm{CAB}$. The choice of $12 \mathrm{cmH}_{2} \mathrm{O}$ for the 
PEEP value was made because it is commonly used in intensive care units to reverse arterial hypoxemia [17]. Further studies for hemodynamics measurements and tissue perfusion with control group and with different groups of PEEP are necessary, both in $\mathrm{CAB}$ and other cardiac procedures.

\section{Conclusion}

In this study, increases in PEEP after $\mathrm{CAB}$ decreased $\mathrm{ScvO}_{2}$ and increased blood lactate, even with higher $\mathrm{O}_{2}$ delivery. In addition, PEEP increases did not interfere in hemodynamics status in $\mathrm{CAB}$ patients, suggesting that in addition to arterial blood gas analysis and hemodynamics measurements, peripheral parameters must be controlled and measured during procedures involving increased PEEP in post-cardiac surgery patients in the intensive care unit.

\section{Acknowledgements}

Not applicable.

\section{Funding}

Not applicable.

\section{Availability of data and materials}

All data generated or analyzed during this study are included in this published article [and its supplementary information files].

\section{Authors' contributions}

VMFM, MFO, PAS, CG e IIKU conception design; VMFM, MFO, ANB e PAX data collect; VMFM, MFO, ANB, PAX, CG, PAS e IIKU data analysis and interpretation; ANB, PAX e PAS conception of tables and figur'es; VMFM, MFO ANB e PAX intellectual contribution; VMFM, MFO, ANB, PAX, CG, PAS e IIKU approved and revised the manuscript.

\section{Competing interests}

The authors declare that are no conflict of interest related to this article.

\section{Consent for publication}

Not applicable.

\section{Ethics approval and consent to participate}

All subjects provided written informed consent, and the study was approved by the Medical Ethics Committee of the Dante Pazzanese Institute of Cardiology, São Paulo, Brazil (protocol number 3535).

\section{Author details}

'Physiotherapy Unit, Dante Pazzanese Institute of Cardiology, Avenida Dr Dante Pazzanese, 500, CEP: 04012-180, Vila Mariana, São Paulo, SP, Brazil. ${ }^{2}$ Physiotherapy Unit, Division of anesthesiology and intensive care unit Federal University of São Paulo (UNIFESP), São Paulo, SP, Brazil. ${ }^{3}$ Physiotherapy Unit, Division of Health Sciences Centre, University of Fortaleza (UNIFOR), Fortaleza, CE, Brazil. ${ }^{4}$ Physiotherapist of Hospital Israelita Albert Einstein (HIAE), São Paulo, SP, Brazil. ${ }^{5}$ Medical doctor of Dante Pazzanese Institute of Cardiology - Division of Intensive Care Unit, São Paulo, SP, Brazil.

Received: 11 July 2016 Accepted: 21 December 2016

Published online: 11 January 2017

\section{References}

1. Duggan M, Kavanagh BP. Pulmonary atelectasis: A pathogenic perioperative entity. Anesthesiology. 2005;102:838-54

2. Padovani C, Cavenaghi OM. Alveolar recruitment in patients in the immediate postoperative period of cardiac surgery. Rev Bras Cir Cardiovasc. 2011; 26:116-21.
3. Hartog C, Bloos F. Venous oxygen saturation. Best Pract Res Clin Anaesthesiol. 2014;28:419-28.

4. Cox CM, Ascione R, Cohen AM, Davies IM, Ryder IG, Angelini GD. Effect of cardiopulmonary bypass on pulmonary gas exchange: A prospective randomized study. Ann Thorac Surg. 2000;69:140-5.

5. Auler Jr JO, Carmona MJ, Barbas CV, Saldiva PH, Malbouisson LM. The effects of positive end-expiratory pressure on respiratory system mechanics and hemodynamics in postoperative cardiac surgery patients. Braz J Med Biol Res. 2000;33:31-42.

6. Lago Borges D, Jose da Silva Nina V, Pereira Baldez TE, De Albuquerque Goncalves Costa M, PereiradosSantos N, Mendes Lima I, LimadaSilvaLula J. Effects of positive end-expiratory pressure on mechanical ventilation duration after coronary artery bypass grafting: A randomized clinical trial. Ann Thorac Cardiovasc Surg. 2014;20:773-7.

7. Borges DL, Nina VJ, Costa Mde A, Baldez TE, Santos NP, Lima IM, Figuerêdo ED, Lula JL. Effects of different peep levels on respiratory mechanics and oxygenation after coronary artery bypass grafting. Rev Bras Cir Cardiovasc. 2013;28:380-5.

8. Luecke T, Pelosi P. Clinical review: Positive end-expiratory pressure and cardiac output. Crit Care. 2005;9:607-21.

9. Kumar A, Anel R, Bunnell E, Habet K, Zanotti S, Marshall S, Neumann A, Ali A, Cheang M, Kavinsky C, Parrillo JE. Pulmonary artery occlusion pressure and central venous pressure fail to predict ventricular filling volume, cardiac performance, or the response to volume infusion in normal subjects. Crit Care Med. 2004;32:691-9.

10. Gutierrez G. Work of breathing, not dysoxia, as the cause of low central venous blood o2 saturation in sepsis. Crit Care. 2016;20:291.

11. Rivers E, Nguyen B, Havstad S, Ressler J, Muzzin A, Knoblich B, Peterson E, Tomlanovich M. Early goal-directed therapy in the treatment of severe sepsis and septic shock. NEJM. 2001;345:1368-77.

12. Dongelmans DA, Hemmes SN, Kudoga AC, Veelo DP, Binnekade JM, Schultz MJ. Positive end-expiratory pressure following coronary artery bypass grafting. Minerva Anestesiol. 2012;78:790-800.

13. Michalopoulos A, Anthi A, Rellos K, Geroulanos S. Effects of positive end-expiratory pressure (peep) in cardiac surgery patients. Respir Med. 1998;92:858-62

14. Malbouisson LM, Brito M, Carmona MJ, Auler JO. Hemodynamic impact of alveolar recruitment maneuver in patients evolving with cardiogenic shock in the immediate postoperative period of myocardial revascularization. Rev Bras Anestesiol. 2008;58:112-23.

15. Perz S, Uhlig T, Kohl M, Bredle DL, Reinhart K, Bauer M, Kortgen A. Low and "supranormal" central venous oxygen saturation and markers of tissue hypoxia in cardiac surgery patients: A prospective observational study. Intensive Care Med. 2011:37:52-9.

16. Szeles TF, Yoshinaga EM, Alenca W, Brudniewski M, Ferreira FS, Auler JO, Carmona MJ, Malbouisson LM. Hypoxemia after myocardial revascularization: Analysis of risk factors. Rev Bras Anestesiol. 2008;58:124-36.

17. Rouby JJ, Lu Q, Goldstein I. Selecting the right level of positive end-expiratory pressure in patients with acute respiratory distress syndrome. Am J Respir Crit Care Med. 2002;165:1182-6.

Submit your next manuscript to BioMed Central and we will help you at every step:

- We accept pre-submission inquiries

- Our selector tool helps you to find the most relevant journal

- We provide round the clock customer support

- Convenient online submission

- Thorough peer review

- Inclusion in PubMed and all major indexing services

- Maximum visibility for your research

Submit your manuscript at www biomedcentral.com/submit
C) BioMed Central 